\title{
育苗初期の温度条件がケール苗の下胚軸伸長および活着力に及ぼす影響
}

\author{
小高宏樹 ${ }^{1} \cdot$ 高橋加奈 $^{2} \cdot$ 相部か扮り ${ }^{2} \cdot$ 鈴木克己 $^{1} \cdot$ 切岩祥和 ${ }^{1 *}$ \\ 1 静岡大学農学部 422-8529 静岡市駿河区大谷 \\ 2 ファンケル総合研究所 244-0806 神奈川県横浜市戸塚区上品濃
}

\section{Effect of Different Temperature Conditions during Early Seedling Stage on Hypocotyl Length and Rooting Ability in Kale}

\author{
Koki Odaka ${ }^{1}$, Kana Takahashi ${ }^{2}$, Kaori Aibe ${ }^{2}$, Katsumi Suzuki ${ }^{1}$ and Yoshikazu Kiriiwa ${ }^{1 *}$ \\ ${ }^{I}$ Faculty of Agriculture, Shizuoka University, Ohya, Suruga-ku, Shizuoka 422-8529 \\ ${ }^{2}$ FANCL Research Institute, FANCL Corporation, Kamishinano, Totsuka-ku, Yokohama, Kanagawa 244-0806
}

\begin{abstract}
In a plug seedling nursery, seedlings are raised densely in a plug seedlings tray. Thus, seedlings may show spindly growth since the cells are dense under high temperature and high humidity conditions. Kale tends to show hypocotyl elongation, it is important to control this elongation for good-quality seedlings, and the result is directly related to the yield. Therefore, in order to clarify the influence of the nursery temperature on the production of good-quality seedlings of Kale, the hypocotyl length and root viability of seedlings were investigated. It was revealed that the hypocotyl length of kale is influenced by temperature, and a high temperature from 4 days after sowing makes it easier to elongate the hypocotyls. Therefore, when treated for 4 days from 4 to 7 days after sowing, the elongation of hypocotyls was suppressed at a low temperature of about $15^{\circ} \mathrm{C}$, but rooting 9 days after planting was improved. This temperature condition had a noticeable effect in the photoperiod, and the high temperature in the photoperiod made it easier to extend the hypocotyls. Moreover, since the root weight did not increase even when treated at a low temperature, it was considered that the improved rooting was due to the increase of root activity. Thus, temperature control in the daytime during the 4 days from the 4 th day after sowing may promote good-quality seedling production in kale nurseries.
\end{abstract}

Key Words : cooling treatment, good-quality seedling, plug seedling nursery, spindly growth seedling

キーワード：良質苗，七ル苗生産，低温処理，徒長苗

\section{緒言}

ケール（Brassica oleracea var. acephala）は栄養価の高い 葉茎菜で，国内では主に加工用途として栽培されている. 生育適温は $20^{\circ} \mathrm{C}$ 前後であるが，耐寒性と耐暑性を併せ持 つため，降雪地域を除いて周年生産が可能な露地野菜の 1 つである. しかし, その生産性は季節によって変動するた め, 加工用に原料を安定供給するためには課題も多い. 著 者らは，このような課題の解決を模索する中で，閉鎖型苗 生産システム（以下，苗テラス，三菱樹脂アグリドリーム (株)）で育苗したセル苗が，ビニルハウスで育苗したセル 苗に比べて, 定植後の活着率が向上し, 定植から 1 か月半 後の生育も良好であったことを報告した（高橋ら，2016）. 岡部（2012）によると，苗テラスで育苗した苗は，下肧軸 が太く短く, 新根の発生も旺盛で根張りが良く, 新葉の展 開が早まると報告されている。 また，人工光下に沶いて強

2018 年 9 月 7 日 受付. 2018 年 12 月 21 日 受理.

本報告の一部は園芸学会平成 28 年度秋季大会で発表した。

* Corresponding author. E-mail: kiriiwa.yoshikazu@shizuoka.ac.jp
光，好適湿度，好適気流速度下で育てた苗は，環境ストレ スにも強くなることも知られて扣り（古在，2009），苗テ ラスは圈場定植後も生育が良好な苗を育成できるすぐれた 技術を有する。しかし，苗テラスで育苗した苗は八ウスで 育苗した慣行苗に比べてコストが高く，収穫物の収益性を 劇的に向上させない限り苗テラスで育苗した苗を露地生産 苗として利用できる見込みは低い，そこで著者らは，なる ベく低コストでより良い苗を育成する条件について検討す ることとした.

セルトレイを利用した育苗は，育苗管理や苗の運搬，定 植作業などを省力できるため，より快適な生産体系を達成 できる技術として急速に普及した。 それに伴い多くの作物 の育苗管理に関する知見が蓄積され，良苗と不良苗の形質 的な特徵も明らかにされた。特に定植後の環境条件が作物 にとって不適な場合に苗の良し悪しが成育に大きく影響す る傾向がある(小寺，1996)。上述したよらに苗テラスで 育苗したケールが定植後の活着と圃場での良好な生育を示 したことは，ケールは育苗条件の影響を受けやすいことを 示し，より生産性を安定化するためにも良い苗を育成する ことは重要である。 
セル成型苗を利用した育苗は短期間で大量に行ら必要が あり，管理を効率化するために密植される. すると受光の 競合や灌水された水分で八ウス内は高温多湿となり，その 結果茥葉が軟弱徒長しやすいといら課題がある. その解決 を目指してセルトレイの容積, 灌水量, 肥料濃度扎よび成 長調節剂の利用など, 苗の徒長防止を目的とした多くの研 究がある（磯崎ら，2000; 竹川・大西，1996）が，ヶールの 育苗に関する研究はない. ケールは不結球性草本で, 茎が 伸長し草丈 $1 \mathrm{~m}$ 程度になり, アブラナ科作物の中では特徵 的な形質を有する。 また，予備実験としてケールとコマッ ナを苗テラスで育苗して苗質を比較したところ, ケールの 下胚軸はコマッナに比べて長いといら特徵を示した（未発 表データ). 通常子葉が緑化する光条件になると下肧軸の 伸長は抑制されるが，ケールでは子葉が緑化したにもかか わらず，コマッナに比べ下肧軸は長かった。 このことは ケールの下肧軸伸長が光によって抑制されにくいか, 別の 要因が関与している可能性がある. そして，苗テラスより も強い光強度条件（自然光）のハウス内で育苗すると下胚 軸はさらに長くなったため, ケールの下肧軸の伸長には光 以外にも温度などの要因子影響すると考えられる．このよ らに下肧軸が長くなった苗は徒長し，根量も少なくなりや すいことから，下肧軸が短く徒長を抑える育苗技術は重要 である.

そこで本実験では，ケールの良苗生産技術の確立を目的 として, 育苗初期に扣ける温度条件がケール苗の下肧軸伸 長と根の活着に及ぼす影響について検討した.

\section{材料および方法}

\section{1. 異なる育苗温度が下胚軸伸長に及ぼす影響（実験 1）}

実験にはコラード系のケール (Brassica oleracea var. acephala）を供試した. 培養土（プライムミックス TKS-2, (株)サカタのタネ) を充填したプラスチック製の 128 穴セ ルトレイに種子を播種し，苗テラスにて子葉が展開するま での 3 日間育苗した. 苗テラスの設定条件は $23^{\circ} \mathrm{C} / 18^{\circ} \mathrm{C}$ (昼 $/$ 夜温), 16 時間 $/ 8$ 時間 (明 $/$ 暗期), 蛍光灯光源を 用いて光強度 $110 \mu \mathrm{mol} \cdot \mathrm{m}^{-2} \cdot \mathrm{s}^{-1}, \mathrm{CO}_{2}$ 濃度 $700 \mathrm{ppm}$ とし, 灌水は園試処方培養液 $2 / 3$ 単位 $\left(\mathrm{EC} 1.8 \mathrm{dS} \cdot \mathrm{m}^{-1}\right)$ を毎日 15 分間底面給液した。播種した種子の 9 割以上の出芽が 確認された播種 4 日後から 14 日後までの 11 日間, 気温 18,23 および $28^{\circ} \mathrm{C}$ 一定, 12 時間日長とした蛍光灯光源を 備えた人工気象器 (LPH-410SPC, (株) 日本医化器械製作 所）にて異なる 3 水準での温度処理を行い, 下肧軸長を毎 日測定した。 人工気象器での栽培・管理条件は, 温度以外 は苗テラスと同じになるように設定し, 灌水も底面給液に より毎日行った. 各処理区当たり 32 株供試した.

\section{2. 播種 $4 \sim 7$ 日後の温度条件が苗の下胚軸長と乾物重に 及ぼす影響（実験 2)}

実験 1 と同様に発芽させた苗を供試し, 人工気象器を用 いて温度処理を行った. 温度処理は播種 $4 \sim 7$ 日後の 4 日
間で， $13 ， 18 ， 23$ および $28^{\circ} \mathrm{C}$ の 4 水準の温度を明期（8 時 間）と暗期（16時間）でそれぞれ組み合わせた 16 処理区 (第 1 表)を設けた. 4 日間の温度処理後は，苗テラスにて 育苗した。温度処理終了直後に下肧軸長を測定し，播種 21 日後に地上部拈よび根の乾物重を測定した。処理区当 たり 32 株を供試した.

\section{4 日間の低温処理開始時期が下胚軸伸長に及ぼす影響} （実験 3）

実験 1 と同様に発芽させた苗に, 人工気象器を用いて $15^{\circ} \mathrm{C}$ の低温処理を行った. $25^{\circ} \mathrm{C}$ 標準温度として，異な る時期に $15^{\circ} \mathrm{C}$ の低温処理を行い, 低温処理後は再び $25^{\circ} \mathrm{C}$ の人工気象器に戻して育苗した。 日長は 12 時間日長とし た. 低温処理は播種後 $4 \sim 14$ 日までの期間において 4 日 間の低温処理を行い，処理するタイミングを 2 日ずつずら すことで処理時期の異なる 6 処理区を設けた。 また $15^{\circ} \mathrm{C}$ での低温処理を行わない $25^{\circ} \mathrm{C}$ 一定で育苗した無処理区も 設けた. 播種 22 日後に下胚軸長を測定した. 処理区ごと に32株を供試した.

\section{4. 低温処理期間が下胚軸伸長に及ぼす影響（実験 4）}

実験 1 と同様に発芽させた苗を供試し，人工気象器を用 いて $15^{\circ} \mathrm{C}$ の低温処理を行った. 播種 4 日後にすべての苗 を $15^{\circ} \mathrm{C}$ の土工気象器に移動し, 処理区ごとに $25^{\circ} \mathrm{C}$ の工 気象器に移動して後述する異なる低温処理期間での処理を 行った。 日長は 12 時間日長とした。 処理は $1,2 ， 3 ， 4$, 5,6 または 7 日間の 7 処理区とし，低温処理しない $25^{\circ} \mathrm{C}$ の人工気象器で育苗した無処理区も設けた. 播種後日数の 違いが，低温処理直後の下肧軸長に影響すると考兄られる ことから，本実験では実験終了後の播種 22 日後に下肧軸 長を測定した。処理区ごとに 32 株を供試した。

\section{5. 育苗初期の温度処理が定植後の苗の活着に及ぼす影響 （実験 5)}

実験 1 と同様に発芽させた苗を供試し，人工気象器を用 いて温度処理を行った. 温度処理は播種 $4 \sim 7$ 日後の 4 日 間， 15,25 または $35^{\circ} \mathrm{C}$ 一定とした人工気象器にて行い, 処理後は $25^{\circ} \mathrm{C}$ 一定の人工気象器にて育苗した. 処理区当 たり 32 株を供試し，温度処理直後の下肧軸長および，播 種 22 日後の地上部拉よび根の乾物重を調査した。 また各 処理区のらち標準的な苗 10 株を引き抜き試験に使用した. 播種時と同じ培養土を詰めた 3 号硬質ポット（直径約 $9 \mathrm{~cm})$ に，播種 22 日後の苗を移植し， $25^{\circ} \mathrm{C}, 12$ 時間日長 の人工気象器にてさらに 9 日間栽培し, その後吉岡ら （1998）の実験を参考に引き抜き抵抗值（gf）を測定した. 引き抜き抵抗值の測定は, オートグラフ (AGS-5kNX, (株)島津製作所）を使用した.オートグラフのクロスヘッ ド部分に，ポットに移植した苗の下肧軸部分を固定し，垂 直に $2.5 \mathrm{~cm} \cdot \mathrm{min}^{-1}$ の速度で引き上げた際の最大抵抗值を 測定した. 


\section{結 果}

\section{1. 異なる育苗温度が下胚軸伸長に及ぼす影響（実験 1）}

ケールの下胚軸長の推移に及ぼす温度条件の影響を調査 したところ，いずれの温度条件でも播種 5～12 日後にか けて伸長したが，その後は汪とんど伸びなくなるといら傾 向を示した (第 1 図). 播種 13 日後の下胚軸は $28^{\circ} \mathrm{C}$ 区で 長かったが， $23^{\circ} \mathrm{C}$ 区と $18^{\circ} \mathrm{C}$ 区では有意差はなかった。温 度処理を開始して 2 日後（播種 6 日後）には， $28^{\circ} \mathrm{C}$ 区の下 胚軸は $18^{\circ} \mathrm{C}$ 区と $23^{\circ} \mathrm{C}$ 区に比べ有意に長くなり, それ以降 では播種 13 日後まで 23 と $18^{\circ} \mathrm{C}$ 区に比べ有意に長かった. このように，18〜 $28^{\circ} \mathrm{C}$ の間では， $28^{\circ} \mathrm{C}$ 区で下肧軸が顕著 に長くなり, 特に播種 $4 \sim 7$ 日後の 3 日間は 1 日 $3 \mathrm{~mm}$ 以 上も伸長し，この 3 日間で $23^{\circ} \mathrm{C}$ 区の播種 13 日後の下肧軸 長よりも長くなった。 これらのことから, 下肧軸の伸長し やすい時期の $28^{\circ} \mathrm{C}$ 程度の高い温度が苗を徒長させ，18〜 $23^{\circ} \mathrm{C}$ の範囲内の温度は下胚軸長に大きく影響しないこと が明らかとなった。

\section{2. 播種 $4 \sim 7$ 日後の温度条件が苗の下胚軸長と乾物重に 及ぼす影響（実験 2)}

播種後 4〜7日にかけての 4 日間，異なる明期温度と暗 期温度を組み合わせた 16 処理を行ったところ, 下肧軸長 は処理の影響を受けた（第 1 表）.

まず明期と暗期の温度を一定とした $13 / 13$ 区，18／18 区，23/23区扣よび28／28 区の 4 区の下胚軸長は，それ ぞれ $12.6 \mathrm{~mm}, 17.4 \mathrm{~mm}, 24.8 \mathrm{~mm}, 37.0 \mathrm{~mm}$ と温度が高いほ

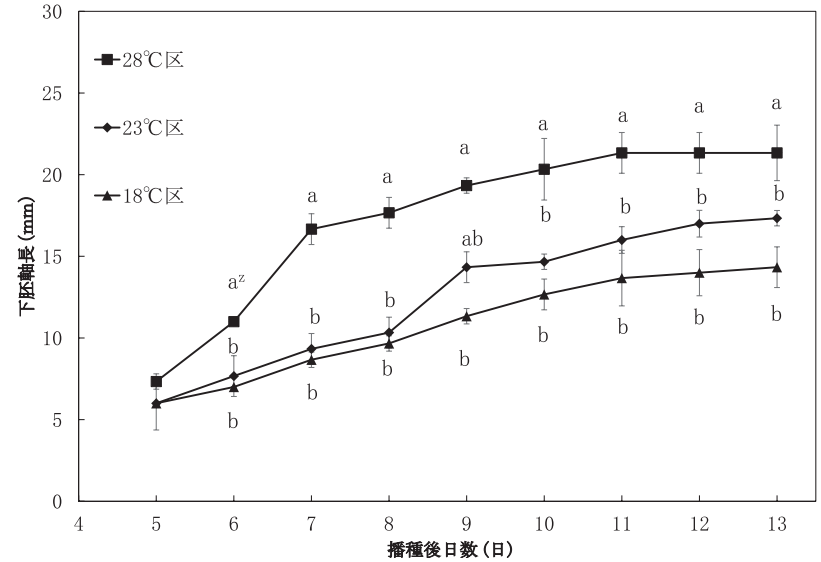

第1図 異なる温度条件が下肧軸伸長に及ぼす影響（実験 1） $\mathrm{z}$ 異なる英小文字は各播種後日数において Tukey の多重 検定において 5\%水準で有意差あり エラーバーは標準偏差

ぞ有意に長かった．暗期温度の上昇についてみると，明期 温度が $13^{\circ} \mathrm{C}$ である処理区に打いては, 暗期温度が $13{ }^{\circ} \mathrm{C}$ $(13 / 13$ 区 $), \quad 18^{\circ} \mathrm{C}(13 / 18$ 区 $), 23^{\circ} \mathrm{C}(13 / 23$ 区 $), 28^{\circ} \mathrm{C}$ (13/28区) と上昇するのに従って下肧軸長が $12.6 \mathrm{~mm}$, $14.7 \mathrm{~mm}, 17.4 \mathrm{~mm}, 20.0 \mathrm{~mm}$ と伸長して打り，他の明期温 度に設定した処理区においても同様の傾向を示した。 そし て，各明期の温度ごとに暗期温度の変化に伴う下肧軸長と の一次回帰式を求めたところ, 明期温度が高い $28^{\circ} \mathrm{C}$ で回 帰式の傾きが大きく，明期 $28^{\circ} \mathrm{C}$ では暗期温度の変化の影

第 1 表 育苗初期の温度処理が苗の形質に及ぼす影響（実験 2)

\begin{tabular}{|c|c|c|c|c|c|c|}
\hline \multicolumn{3}{|c|}{ 処理区 } & \multirow{2}{*}{$\begin{array}{c}\text { 下肧軸長 } \\
(\mathrm{mm})\end{array}$} & \multicolumn{3}{|c|}{ 乾物重 (g) } \\
\hline & 明期 $(8 \mathrm{~h})$ & 暗期（16h） & & 地上部 & 根 & $\mathrm{T} / \mathrm{R}$ 比 \\
\hline $13 / 13$ 区 & \multirow{4}{*}{$13^{\circ} \mathrm{C}$} & $13^{\circ} \mathrm{C}$ & $12.6 \mathrm{~h}^{\mathrm{Z}}$ & $0.27 \mathrm{bc}$ & 0.06 & 4.40 \\
\hline $13 / 18$ 区 & & $18^{\circ} \mathrm{C}$ & $14.7 \mathrm{~h}$ & $0.31 \mathrm{abc}$ & 0.12 & 3.03 \\
\hline $13 / 23$ 区 & & $23^{\circ} \mathrm{C}$ & $17.4 \mathrm{gh}$ & $0.31 \mathrm{abc}$ & 0.10 & 3.23 \\
\hline $13 / 28$ 区 & & $28^{\circ} \mathrm{C}$ & $20.0 \mathrm{fg}$ & $0.29 \mathrm{abc}$ & 0.10 & 3.46 \\
\hline $18 / 13$ 区 & \multirow{4}{*}{$18^{\circ} \mathrm{C}$} & $13^{\circ} \mathrm{C}$ & $16.6 \mathrm{gh}$ & $0.32 \mathrm{abc}$ & 0.09 & 4.00 \\
\hline $18 / 18$ 区 & & $18^{\circ} \mathrm{C}$ & $17.4 \mathrm{gh}$ & $0.31 \mathrm{abc}$ & 0.09 & 3.36 \\
\hline $18 / 23$ 区 & & $23^{\circ} \mathrm{C}$ & $21.5 \mathrm{fg}$ & $0.26 \mathrm{bc}$ & 0.07 & 4.34 \\
\hline $18 / 28$ 区 & & $28^{\circ} \mathrm{C}$ & 23.4 ef & $0.23 \mathrm{c}$ & 0.07 & 3.65 \\
\hline $23 / 13$ 区 & \multirow{4}{*}{$23^{\circ} \mathrm{C}$} & $13^{\circ} \mathrm{C}$ & $21.3 \mathrm{fg}$ & $0.36 \mathrm{abc}$ & 0.08 & 4.77 \\
\hline $23 / 18$ 区 & & $18^{\circ} \mathrm{C}$ & 23.3 ef & $0.37 \mathrm{abc}$ & 0.10 & 3.93 \\
\hline $23 / 23$ 区 & & $23^{\circ} \mathrm{C}$ & $24.8 \mathrm{def}$ & $0.41 \mathrm{a}$ & 0.10 & 4.51 \\
\hline $23 / 28$ 区 & & $28^{\circ} \mathrm{C}$ & $30.2 \mathrm{bcd}$ & $0.38 \mathrm{ab}$ & 0.09 & 4.88 \\
\hline $28 / 13$ 区 & \multirow{5}{*}{$28^{\circ} \mathrm{C}$} & $13^{\circ} \mathrm{C}$ & 28.0 cde & $0.35 \mathrm{abc}$ & 0.07 & 5.80 \\
\hline $28 / 18$ 区 & & $18^{\circ} \mathrm{C}$ & $31.4 \mathrm{bc}$ & $0.36 \mathrm{abc}$ & 0.08 & 5.17 \\
\hline $28 / 23$ 区 & & $23^{\circ} \mathrm{C}$ & $34.3 \mathrm{ab}$ & $0.30 \mathrm{abc}$ & 0.05 & 6.15 \\
\hline \multirow[t]{2}{*}{$28 / 28$ 区 } & & $28^{\circ} \mathrm{C}$ & $37.0 \mathrm{a}$ & $0.31 \mathrm{abc}$ & 0.06 & 5.34 \\
\hline & & ANOVA & $P<0.05$ & $P<0.05$ & n.s. ${ }^{\mathrm{y}}$ & n.s. \\
\hline
\end{tabular}

$\mathrm{z}$ 調査項目内に扎いて異なる英小文字はTukey の多重検定において 5\%水準で有意差あり

$\mathrm{y}$ 有意差なし 


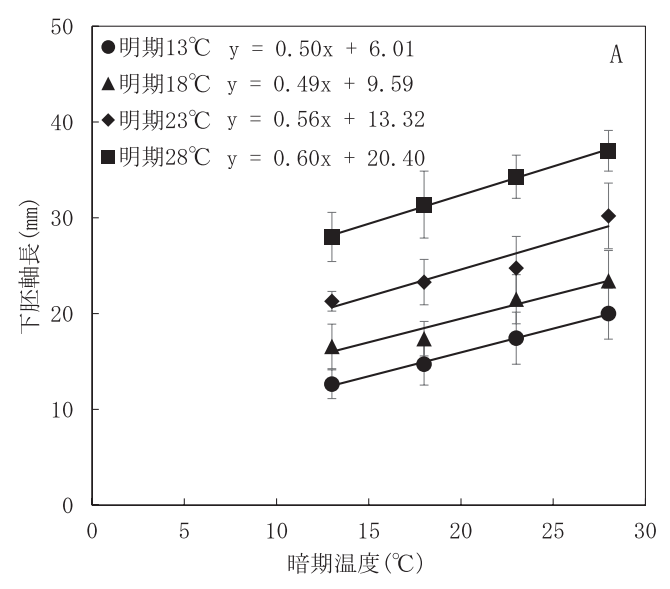

第 2 図 暗期温度（A）および明期温度 エラーバーは標準偏差

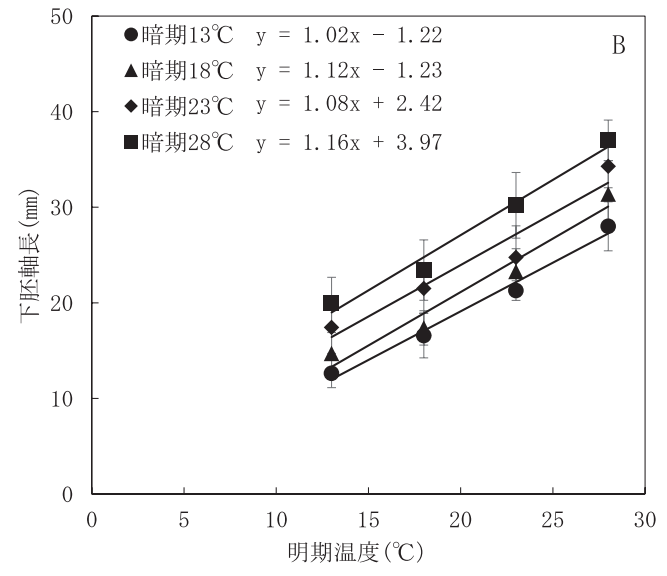

（B）が下胚軸長に及ぼす影響（実験 2）

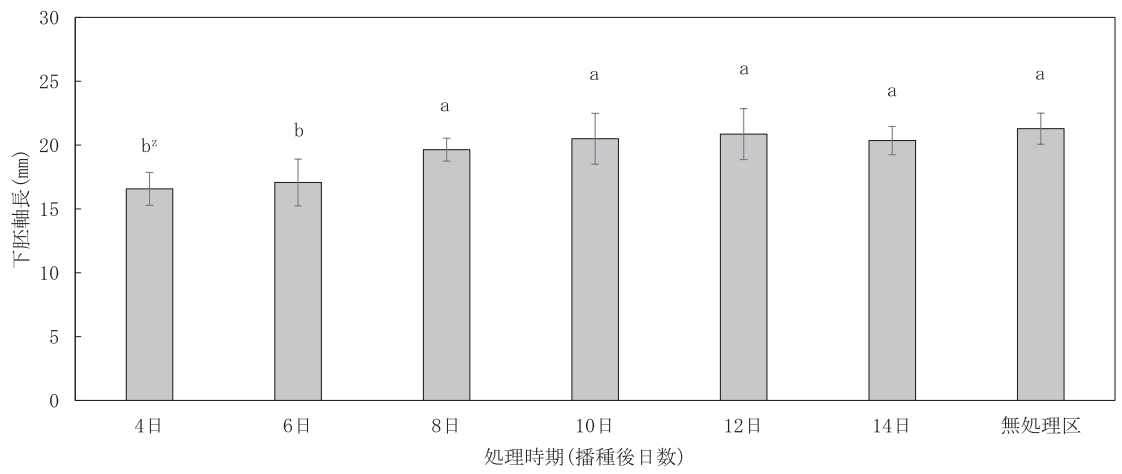

第 3 図 低温処理開始時期が下肧軸長に及ぼす影響（実験 3) z 異なる英小文字は Tukey の多重検定に拈いて $1 \%$ 水準で有意差あり エラーバーは標準偏差

響を受けやすい可能性が示された（第 2 図 A）。同様に明 期温度の变化の影響についてみると, 暗期温度が $13^{\circ} \mathrm{C} て ゙$ ある処理区に打いても，明期温度が $13^{\circ} \mathrm{C}(13 / 13$ 区 $)$, $18^{\circ} \mathrm{C}(18 / 13$ 区 $), 23^{\circ} \mathrm{C}(23 / 13$ 区 $), 28^{\circ} \mathrm{C}(28 / 13$ 区 $)$ と上昇するのに従って下胚軸長が $12.6 \mathrm{~mm}, 16.6 \mathrm{~mm}$, $21.3 \mathrm{~mm}, 28.0 \mathrm{~mm}$ と有意に伸長し，他の暗期温度に設定し た処理区に打いても同様の傾向を示した. 次に各暗期の温 度ごとに明期温度の変化に伴う下肧軸長との一次回帰式を 求めた。 その結果, 回帰式の傾きは暗期温度の上昇による 傾きよりも約 2 倍程度に大きくなり, 明期温度の上昇は, 下肧軸をより伸長する傾向を示した（第2図B）.

播種 4 7 日後の温度条件は, 播種 21 日後の苗の地上 部乾物重にも影響し (第 1 表), $23 / 23$ 区で最大值の $0.41 \mathrm{~g}$, $18 / 28$ 区で最小值の $0.23 \mathrm{~g}$ となった. しかし処理区全体 の地上部乾物重について, 明期温度, 暗期温度抢よび平均 温度との相関を調べたところ，相関係数はそれぞれ $\mathrm{r}=0.50, \mathrm{r}=-0.15$ 打よび $\mathrm{r}=0.08$ となり, 地上部乾物重と 温度条件との間に相関はなかった．根乾物重は処理による 有意差がなかった，処理区ごとに $\mathrm{T} / \mathrm{R}$ 比を求めたところ, 明期温度を $28^{\circ} \mathrm{C}$ に設定した 4 つの処理区に抢いては,
$5.17 \sim 6.15$ と比較的高く, 地上部は大きくなるが，地下部 が小さくなる傾向が示された。

\section{4 日間の低温処理開始時期が下胚軸伸長に及ぼす影響 (実験 3)}

$15^{\circ} \mathrm{C}$ の低温処理を開始する時期によって播種 22 日後の 下肧軸長は影響を受けた（第 3 図）。播種 4 日後と 6 日後 から低温処理を開始した両処理区の下肧軸長は有意に短 く, 播種 8 日後以降からの低温処理を行った処理区は対照 区と差がなくケールの下肧軸伸長を抑制するための低温 処理は，播種 6 日後までに開始する必要があることが明ら かとなった。

\section{4. 低温処理期間が下胚軸伸長に及ぼす影響（実験 4）}

播種 22 日後に扔沙苗の下肧軸長は, 播種 4 日後から の $15^{\circ} \mathrm{C}$ の低温処理によって有意に影響を受けた（第 4 図）. 低温処理を行わなかった無処理区と比較して，1 日以上の 低温処理により，下肧軸長は短くなった４日から 7 日ま での低温処理では，処理期間が長くなっても下肧軸長に有 意差はなかった。 


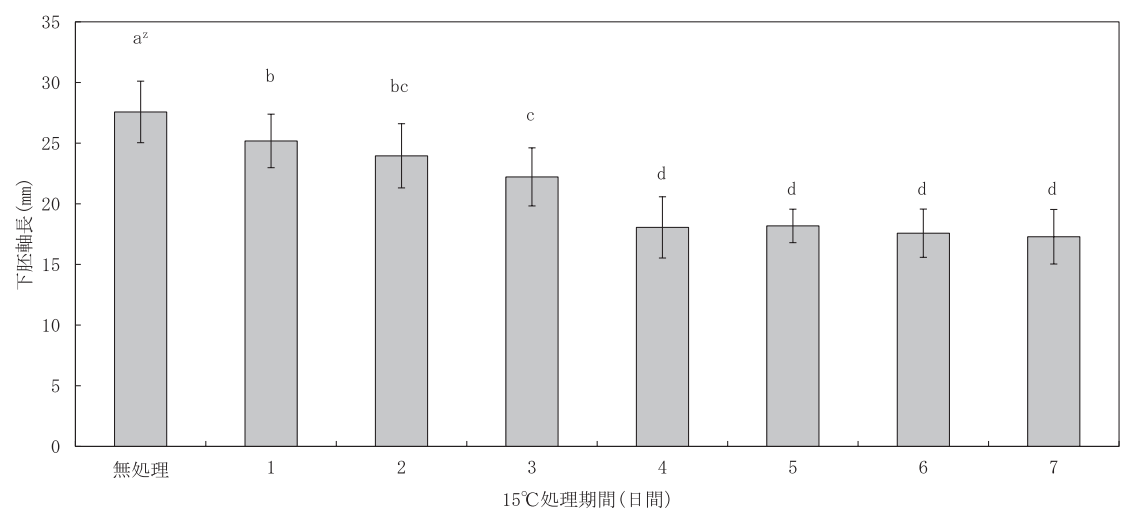

第 4 図 低温処理期間が下肧軸長に及ぼす影響（実験 4）

$\mathrm{z}$ 異なる英小文字は Tukey の多重検定において $1 \%$ 水準で有意差あり エラーバーは標準偏差
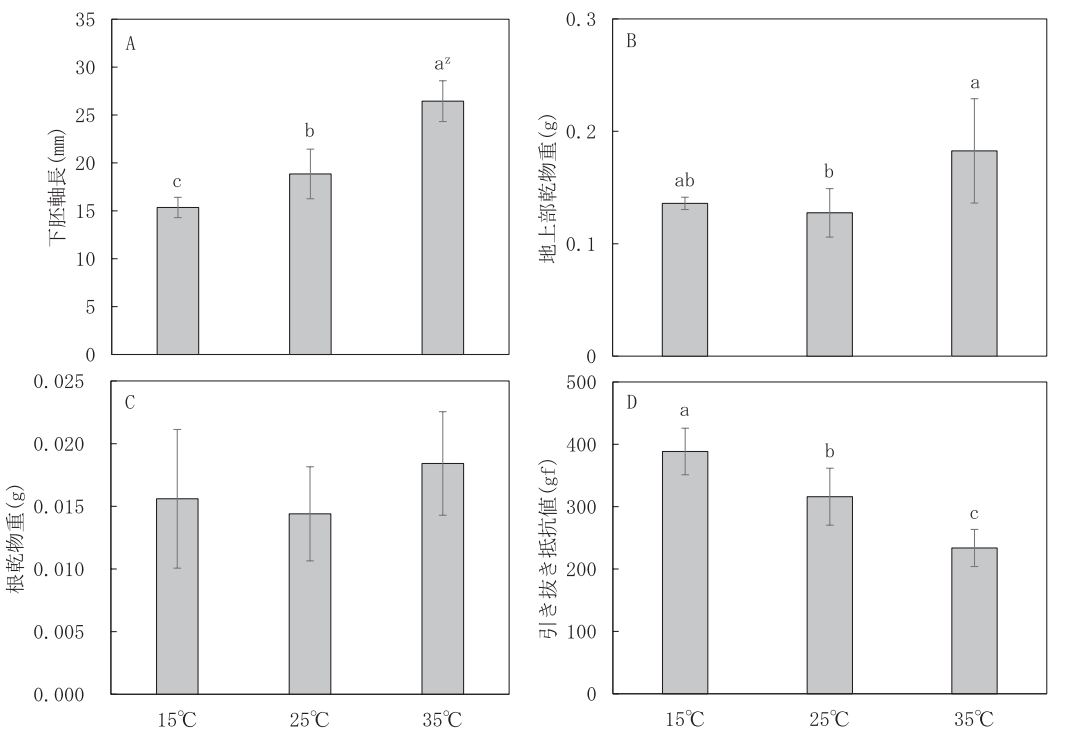

第 5 図 育苗初期の温度処理が苗の形質および定植後の活着に及ぼす影響（実験 5) $\mathrm{z}$ 異なる英小文字は Tukeyの多重検定において 5\%水準で有意差あり エラーバーは標準偏差

\section{5. 育苗初期の温度処理が定植後の苗の活着に及ぼす影響 (実験 5)}

播種 4〜 7 日の 4 日間での温度処理は処理直後の下肧軸 長に影響し, 処理温度が高くなるにつれて有意に伸長した (第 5 図 A).ささらに播種 22 日後の苗の地上部乾物重にも 温度処理は影響し， $25^{\circ} \mathrm{C}$ 区に対して $35^{\circ} \mathrm{C}$ 区で有意に増加 した（第 5 図 B)。一方で根の乾物重に有意差はなかった (第 5 図 C). こ水らの苗をポットに移植して, 9 日後の苗 の活着力を引き抜き抵抗值として比較したところ, その値 は $15^{\circ} \mathrm{C}$ 区で最大となり, 処理温度が高くなるにつれて有 意に減少した（第 5 図D）。

\section{考察}

ケールの下胚軸長は育苗初期に温度の影響を受け, 温度 が高くなると播種後 $5 \sim 7$ 日にかけて下胚軸が急激に長く
なった。そこで，下肧軸伸長の抑制を目的としてこの時期 の育苗温度を低くしたところ，伸長の抑制効果が確認され た。 このようにケールの下肧軸は温度によって伸長が影響 されやすく，本実験の結果からケールの下胚軸の伸長を抑 制する温度処理は，播種 $4 \sim 7$ 日後の 4 日間を $15^{\circ} \mathrm{C}$ で処理 することが望ましいと考兄られた。このような下肧軸長に 及ぼす温度の影響は，下胚軸の長短が外観的な品質として 重要な要素となるカイワレダイコンでも同様で， $15^{\circ} \mathrm{C}$ 区 $43 \mathrm{~mm}, 20^{\circ} \mathrm{C}$ 区 $61 \mathrm{~mm}, 25^{\circ} \mathrm{C}$ 区 $79 \mathrm{~mm}$ と温度の上昇ととも に長くなることが報告されている（松本ら，2009）。この ような下肧軸の伸長に及ぼす温度の影響についてハボタン (Brassica oleracea var. acephala. 'Tsugumi') を供試して $20^{\circ} \mathrm{C}$ 一定の条件下での推移を調査した結果によると，その伸長 は1 日のらちでも一定の緩急りズムを示し，そのリズムは 日数が経過する活ど小さくなり, 結果的に伸長量も小さく 
なる傾向を示し (清水ら, 2008a), ケールでも同様の特徵 を示した.さらに明暗条件に括ける八ボタンの下肧軸伸長 の詳細な解析により，その伸長は明期ではわずかで，暗期 の開始後に顕著に長くなるといら特徴を示した。 その伸長 量は昼夜温較差（DIF）の影響を受け， $20^{\circ} \mathrm{C}$ 一定に比べ $25^{\circ} \mathrm{C} / 15^{\circ} \mathrm{C}$ (+10DIF) 区で大きく, $15^{\circ} \mathrm{C} / 25^{\circ} \mathrm{C}$ (-10DIF) 区で小さくなり，暗期の温度が低い汪ど促進されたと報 告されている. これに対し, ヒャクニチソウ (Zinnia elegance L.) の下肧軸伸長は-10DIF $\left(15^{\circ} \mathrm{C} / 25^{\circ} \mathrm{C}\right)$ 区で 大きく $+10 \mathrm{DIF}\left(25^{\circ} \mathrm{C} / 15^{\circ} \mathrm{C}\right)$ 区で小さくなり，特に暗期 に打ける伸長は温度が高い汪ど大きかった（清水ら， 2008b). ケールの下胚軸伸長では, 暗期に比べ明期の温度 の方が大きく影響する傾向を示したが，DIF 条件による影 響はみられなかった。このよらに，下肧軸の伸長に対する 温度の影響は植物種によっても異なり，その伸長を制御す るメカニズムは作物によって特異的である可能性がある.

下肧軸伸長に対する光条件や植物ホルモンが関与する仕 組みについては, 光受容体や植物ホルモンの作用機構が明 らかになっていることから多くの報告がある（Chenら， 2013; Favero ら, 2017; Kunihiro ら, 2010). その一方で, 植 物が温度条件に敏感に応答する仕組み解明の鍵となる, 温 度シグナルの受容センサーに関しては明らかでなかったこ とから，温度が下肧軸伸長を制御する仕組みの解明は遅れ ていた. Jung ら（2016）はシロイヌナズナのフィトクロム の 5 重変異体 (phyABCDE) を用いた解析により, 野生型 の下胚軸伸長でみられた温度応答が変異体でみられなく なることを明らかにした。 そして，この変異体と野生型の 高温 $\left(27^{\circ} \mathrm{C}\right)$ 条件下での転写産物の日変化のパターンか ら, 温度形態形成が主に夜に起こり, PHYTOCROME INTERACTING FACTOR 4 (PIF4) などが関与していること を明らかにした。 また， Gangappa・Kumar（2017）は，温 度上昇による肧軸伸長は温度によるシグナルが PIF4を経 由してオーキシン生合成に関与する YUC 8 や細胞肥大に関 与する $E X P 8, X T R 7$ 発現を増加させたことを明らかに し, これらの知見から肧軸伸長のメカニズムに対する温度 応答が分子レベルでも解明されつつある. ケールに関して は下胚軸伸長への植物ホルモンの関与や，分子生物学的な 解析に基づく知見はないが，アブラナ科作物の中でも旺盛 な茎伸長を特徵とする植物として, 初期成長で温度に敏感 に反応した習性は，下肧軸を含めた細胞伸長に関する興味 深い材料となるかもしれない.

本実験では，良質苗の特徵として定植後の活着も指標と した。著者らは，苗テラスで育成した苗が定植後も良好な 初期生育を示し，活着率が高いことを確認して未り（高橋 ら，2016）, 徒長を抑えた苗は, 圃場での旺盛な生育が得 られると期待される。 そこで, 育苗初期の温度処理が定植 後の活着に及ぼす影響を評価したところ，処理温度が低い 䚾ど引き抜き抵抗值が高かった。この引き抜き抵抗值は, 定植後の根の増加量と高い相関があることがキャベッで報
告されている（吉岡ら，1998）。本実験において定植前の 苗の根の乾物重は, 温度処理によって影響されなかったこ とから，育苗初期の低温処理は根量を増加させるのではな く，定植後の発根力に影響した可能性がある. 高温条件に 扣ける根の呼吸活性の低下は, 光合成産物の根への分配率 の低下や，同化産物の消耗が呼吸によって増大することに よるものである（宾戸・熊倉，1994）。従って，高い呼吸 活性を維持できた低温の処理ほど発根のために多くのエネ ルギーを利用でき，高い引き抜き抵抗值を示したと推察さ れる。苗テラスの苗は，新根の発生が旺盛で活着力が向上 することが知られて扣り (岡部, 2012)，ケールに扣いて は下胚軸の伸長を抑える低温の処理により苗テラスで期待 される活着の向上を得ることができた.

以上のように育苗期に打ける温度条件はケールの良質苗 生産のための重要な環境要因の一つであり, 育苗初期の日 中の温度が高いほど下肧軸伸長を促進し，苗の $\mathrm{T} / \mathrm{R}$ 比を 増加させ，定植後の活着を低下させることが明らかとなっ た。ケールを周年生産している現地に拈いては，8月に秋 植え用の育苗をハウスで行っており，高温育苗を避けるこ とができず徒長気味の苗となる。その結果圃場での活着率 が低下する可能性が大きく，収量を確保するらえでの課題 となっている，育苗環境が高温多湿の場合，多くの作物で 葉形が細長く徒長し，苗が絡まって定植時にダメージを与 えると同時に著しく作業性を低下させる（深澤，1997; 吉 岡，1998)。キャベッの育苗において，高温は発芽および 苗の生育を妨げてしまらため，風通しを良くし，遮光やミ スト灌水によって温度を下げる工夫や，白色セルトレイの 使用などの高温対策が行われている(小寺, 1996)。しか し，八ウス育苗において育苗環境を常に快適に制御するた めの対策は, 露地葉物野菜にとっては経済的な観点からも 困難なことも多い。本実験は約 3 週間の育苗期間に打ける ケール苗の生育特性を理解し，良苗を育成する条件を明ら かにすることを目的として行った．その結果，播種 $4 \sim 6$ 日後から最低 4 日間の低温処理が良苗生産にとって有効で あった。このような短期間の温度処理で下肧軸の伸長を抑 えた良質なセル苗が生産できればコストを抑えた育苗技術 としても期待できる。そして，ょり収益性の高いケールの 生産が可能な技術開発を目指し，苗テラス等の育苗施設も 活用した作型についても検討したいと考えている.

\section{摘 要}

露地野菜のセル育苗は, 高温多湿で過密植条件で行わ れ，徒長気味の苗となりやすい。下肧軸が伸長しやすい ケールに扣いても, 圃場での苗の活着率には苗の良し悪し が影響し，収量性にも影響する。そこで，ケールの良質苗 生産のための育苗温度条件の影響について，苗の下胚軸長 および根の活着力を調査した。 ケールの下肧軸長は温度に 影響され，播種 4 日後からの育苗温度が高いと下胚軸が伸 長しやすく，育苗初期の温度条件が重要な環境要因である 
ことが明らかとなった，そこで下肧軸が伸長しやすい播種 4〜 7 日後までの 4 日間を $15^{\circ} \mathrm{C}$ 程度の低温で処理すると下 肧軸の伸長が抑制され, 定植後の活着が向上した. この温 度条件は明期に特に大きく影響し，明期の高温は下肧軸が 伸長しやすいため不適であると考えられた。 また低温で処 理しても根量は増加しなかったことから, 活着力の増大は 根の活性の増大によるものと推察された. 以上のことか ら, ケールの育苗に拈いて, 播種 4 日後からの4 日間に打 ける日中の気温を低く管理することが良質な苗生産につな がると考えられた。

\section{引用文献}

Chen, J., K. Sonobe, N. Ogawa, S. Masuda, A. Nagatani, Y. Kobayashi and H. Ohta. 2013. Inhibition of Arabidopsis hypocotyl elongation by jasmonates is enhanced under red light in phytochrome B dependent manner. J. Plant Res. 126: $161-168$.

Favero, D., K. N. Le and M. Neff. 2017. Brassinosteroid signaling converges with SUPPRESSOR OF PHYTOCHROME B4-\#3 to influence the expression of SMALL AUXIN UP RNA genes and hypocotyl growth. Plant J. 89: 1133-1145.

深澤郁男. 1997. 七ル成型苗の苗質. 基 291-294. 農業技 術大系野菜編 2. トマト. 追録第 22 号. 農文協. 東京.

Gangappa, S. N. and S. V. Kumar. 2017. DET1 and HY5 Control PIF4-mediated thermosensory elongation growth through distinct mechanisms. Cell Rep. 18: 344-351.

磯崎真英・戸谷 孝・小西信幸・田中一久. 2000. キャベ ツ, ブロッコリーのセル成型苗育苗技術に関する研 究. 三重農技七研報. 27: 15-26.

Jung, J., M. Domijan, C. Klose, S. Biswas, D. Ezer, M. Gao, A. K. Khattak, M. Box, V. Charoensawan, S. Cortijo, M. Kumar, A. Grant, J. C. W. Locke, E. Schafer, K. Jaeger and P. Wigge. 2016. Phytochromes function as thermosensors in Arabidpsis. Science 354: 886-889.

小寺孝治. 1996. 七ル成型苗移植栽培. 基 117-134. 農業 技術大系野菜編 7. キャベッ・ハクサイ・ホゥレンソ ウ・ツケナ類. 追録第 21 号. 農文協. 東京.

古在豊樹. 2009. 人工光型植物工場. p. 121-148. 古在豊
樹編著. 太陽光型植物工場 先進的植物工場のサステ ナブル・デザイン. オーム社. 東京.

Kunihiro, A., T. Yamashino and T. Mizuno. 2010. Phytochromeinteracting factors PIF4 and PIF5 are implicated in the regulation of hypocotyl elongation in response to blue light in Arabibopsis thaliana. Biosci. Biotechnol. Biochem. 74: 2538-2541.

松本恵子・多田雄一・清水 浩・涉澤 栄. 2009. カイワ レダイコン (Raphanus sativus L. 'Kaiwaedaikon (Japanese radish sprout)'）の生育抏よび抗酸化活性に与える 気温の影響. 植物環境工学. 21: 29-34.

岡部勝美. 2012. 葉菜類の育苗を「苗テラス」で行らこと で, どのくらい本圃生産量がUPしますか? 八イド ロポニックス. 25: 48.

清水浩・對馬ゆかり・小松佳菜子. 2008a. 八ボタン (Brassicca oleracea var. acephala. 'Tsugumi') 下胚軸の DIF 環境下に打数伸長解析. 植物環境工学. 20: 2125 .

清水 浩・對馬ゆかり・小松佳菜子・椎木友朗・西津貴 久・Kiong, C. V.・近藤 直. 2008 b. 明暗期温度がジ ニア (Zinnia elegance L.) の伸長成長に与える影響. 植物環境工学. 20: 253-256.

宍戸良洋・熊倉裕史. 1994. トマトに打ける光合成・蒸 散・光合成産物の転流・分配抒よび根の呼吸に及ぼす 培地温の影響. 園学雑. 63: 81-89.

高橋加奈・小高宏樹・相部か未り・切岩祥和. 2016. 閉鎖 型苗生産システムで育苗したケールの収量拈よび品 質. 園学研. 15 (別 1): 178.

竹川昌宏・大西忠男. 1996. キャベッセル成型苗の徒長防 止のための生育調節剂利用. 兵庫農技七研報 (農). 44: $35-38$.

吉岡 宏. 1998. 苗の生育診断のポイント. 基 153-155. 農 業技術大系野菜編 6. レタス・サラダナ・セルリー・ 八ナヤサイ・ブロッコリー，追録第 23 号．農文協．東 京.

吉岡 宏・清水恵美子・福岡信之・藤原隆広・佐藤文生. 1998. 苗の引き抜き抵抗を利用したキャベッセル成型 苗の発根力評価. 園学雑. 67: 584-594. 